\title{
INDUCTION OF MICRONUCLEI AND SISTER CHROMATID EXCHANGES IN SHEEP LYMPHOCYTE CULTURES BY HERBICIDE CHLORIDAZON
}

\author{
E. PIEŠOVÁ, K. ŠIVIKOVÁ \\ Department of Veterinary Genetics, University of Veterinary Medicine, Kosice, Slovak Republic
}

Received August 4, 1997

Accepted January 15, 1998

\begin{abstract}
Piešová, E., K. Šiviková: Induction of Micronuclei and Sister Chromatid Exchanges in Sheep Lymphocyte Cultures by Herbicide Chloridazon. Acta vet. Brno 1997, 66: 229-234.

The effect of herbicide chloridazon was studied using induction of micronuclei (MN) and sister chromatid exchanges (SCE) in vitro. Inductions of these markers were measured in sheep peripheral lymphocytes with and without of metabolic activation (S-9 mix). Chloridazon affected both MN and SCE at all of the concentrations tested. Significant increases $(\mathrm{P}<0.05)$ were achieved at $7 \times 10^{-4} \mathrm{M}$ in both tests. Neither of the lower concentrations $\left(7 \times 10^{-5} \mathrm{M}\right.$ and $\left.7 \times 10^{-6} \mathrm{M}\right)$ did affect the MN or SCE values.

The herbicide was also tested in presence of an S 9 mix activating fraction, in which significant increases of SCE levels were determined for concentrations of $7 \times 10^{-5} \mathrm{M}$ and $7 \times 10^{-4} \mathrm{M}(\mathrm{P}<0.05$ and 0.01 , respectively).

No induction of the cell cycle delay or reduction of proliferation index (PI) were detected.

Chloridazon has, as shown in our assays. a weak influence on induction of tested chromosomal changes.
\end{abstract}

Sheep, peripheral lymphocytes, micronuclei, sister chromatid exchanges, chloridazon

Genotoxicity of agricultural chemical agents has been tested over the last several decades and continues to the present days (Kale et al. 1995). In modern industrial society pesticides have numerous invaluable properties. On the other hand, however, they may induce a wide array of health problems, ranging from myelotoxicity to cytogenetic change and carcinogenic effects. Sheep and cattle may be directly exposed to these chemical agents on pasture. Genotoxic evaluation of these compounds, using different assays has an important role in protection and preservation of health in these animal populations. Even an extensive use of pesticides in agriculture reduced the populations of some free living species, such as Coturnix coturnix (Canters and Snoo 1993).

Preliminary studies of the mutagenic or carcinogenic potential of pesticides indicate that although these substances are toxic they yield only negative or mildly positive results in different genetic tests such as mutagenicity assays (Hrelia et al. 1990; Hrelia et al. 1991), they may induce specific $\mathrm{P} 450$ isoenzymes that are responsible for pharmacokinetic interactions with other xenobiotics. Moreover, they may alter the metabolic activity of precarcinogens that are converted into carcinogens during activation.

The vegetation is one way how xenobiotics penetrate into the food chain. Plants take up heterogeneous mixtures of genotoxic compounds and cumulate them on the surface and/or metabolize them in their structures. In this way any living creatures may be affected by adverse impacts of their environment (Pokorná et al. 1996).

Among pesticides, herbicides constitute an important proportion (about $65 \%$ ) of their production (Delvo 1987). The widespread use of these chemicals, together with the fact that they are usually applied directly onto the soil, affects the environment. Numerous studies have reported on their potential genotoxic hazard both for man and animals.

Burex Eko (based on the effective substance of chloridazon) is a product of Istrochem Bratislava, (Slovak Republic). It has been used in agriculture since 1962. The active 
substance is chloridazon, and it belongs to pyridazinone (triazole) herbicide group. It is a selective systemic herbicide rapidly absorbed by plant roots. It is employed for destruction of broad-leaved weeds in sugar beet and fodder beet fields.

The detoxifying mechanism of the beets is based on a metabolic change of the effective substance (chloridazon) to an ineffective aminoglucozide substance, and enables selective application of this herbicide (Cremlyn 1985). Burex Eko is used in diluted form in agriculture (5-7.5 litre per hectare before or during seedtime in spring).

Three different modes of action in plants have been reported for pyridazinone herbicides: inhibition of photosynthesis. inhibition of carotenoid biosynthesis and influence on lipid biosynthesis. Among these, only chloridazon (pyrazone) appears to act as an inhibitor of photosynthesis (Mlynarčíková et al.1996).

To our knowledge, there are no reports available describing the cytogenetic or genotoxic effects of chloridazon on human or animal cells. In the present study, the capability of chloridazon to induce genetic impairment was evaluated in the MN and SCE assays, respectively, as many investigators consider MNi and SCEs as indirect indicators of genetic damage (Norppa et al. 1993; Carrano et al. 1978; Morimoto et al. 1985), while chromosome aberrations (CA) are usually used for risk assessment of chemical agents (Tucker and Preston 1996).

\section{Materials and Methods}

Chloridazon (5-amino-4-chloro-2-phenyl-pyridazin-3-one, purity: 92.6\%, Istrochem. Slovak Republic) was dissolved in dimethyl sulphoxide (DMSO) and freshly prepared before each experiment at concentrations of $7 \times 10^{-4} \mathrm{M}, 7 \times 10^{-5} \mathrm{M}$ and $7 \times 10^{-6} \mathrm{M}$.

Positive controls: mitomycin C (MMC, CAS no. 50-07-7. Sigma, St.Louis, MO. USA) at concentration of $0.4 \mu \mathrm{M}$ was dissolved in bidistilled water and used in the $\mathrm{MN}$ test.

Sodium azide (NaN3, $1 \mu \mathrm{g} / \mathrm{ml}$, Sigma. St.Louis, MO. USA) and cyclophosphamide (CPA, $4 \mu \mathrm{g} / \mathrm{ml}$, Jenapharm, Ankerwerk. Rudolstadt, Germany) were used as positive control agents in the absence or in the presence of the metabolic activation ( $99 \mathrm{mix}$ ), respectively.

An S9 fraction (10\% of the culture volume) was freshly prepared from livers of male mice treated with Aroclor 1254 (Supelco. Bellefonte. PA. USA) according to the method described by M a r o n and A mes (1983). It was used for cytogenetic assays along with cofactors giucose-6-phosphate (Aldrich. Milwaukee. WI, USA) and NADP (Sigma, St. Louis, MO. USA). The lymphocyte cultures with $S 9$ and the herbicide were cultured together for $2 \mathrm{~h}$, then the cell cultures were rinsed. and placed in fresh medium.

\section{Lymphocyte cultures}

Lymphocyte cultures were prepared by adding $0.5 \mathrm{ml}$ of heparinized whole blood from 2 healthy donors (2-yearold Merino sheep) to $10 \mathrm{ml}$ of chromosome medium RPMI 1640 supplemented with $15 \%$ fetal calf serum (BOFES, Workplace for Special Culture Sera. Brno, Czech Republic), antibiotics (penicillin $250 \mathrm{U} / \mathrm{ml}$ and streptomycin $250 \mu \mathrm{g} / \mathrm{ml}$ ) and phytohaemagglutinin (PHA, $180 \mu \mathrm{g} / \mathrm{ml}$, Wellcome, Darford, England).

Lymphocyte cultures for MN assay were incubated at $37^{\circ} \mathrm{C}$ for $72 \mathrm{~h}$. Cytochalasin B (Cyt. B, Sigma. St. Louis, MO, LSA) was added at $44 \mathrm{~h}$ after start of the culture, at a concentration of $3 \mu \mathrm{g} / \mathrm{ml}$. The tested substance was added $24 \mathrm{~h}$ after culture initiation and was present until the end of cultivation (Surralés et al. 1995).

Lymphocyte cultures for SCE were incubated at $37{ }^{\circ} \mathrm{C}$ for 72 h. 5-bromodeoxyuridine (BrdU, Sigma, St. Louis, MO. USA) at a concentration of $8 \mu \mathrm{g} / \mathrm{ml}$ was added to all cultures for the last $48 \mathrm{~h}$ of cultivation.

Lymphocyte cultures without $\mathrm{S} 9 \mathrm{mix}$ were exposed to chloridazon for the last $24 \mathrm{~h}$ of cultivation. whereas cultures with S9 were treated with the herbicide for $2 \mathrm{~h}$. The cells were then removed and placed in fresh medium.

Colchicin (Merck, Darmstadt. Germany) was added at a concentration of $5 \mu \mathrm{g} / \mathrm{ml} 2 \mathrm{~h}$ before harvest.

Slides for the MN test were stained with 5\% Giemsa (Merck. Darmstadt. Germany) in Sörensen phosphate buffer pH 6.8 for $15 \mathrm{~min}$.

Slides for SCE were prepared by the conventional air-drying technique and after staining with $5 \%$ Giemsa (Merck, Darmstadt, Germany), pH 8 to differentiate sister chromatids (Perry and Wolff 1974). 
$M N$ and SCE analysis

The induction of $\mathrm{MN}$ was evaluated by scoring a total of 1000 binucleated (BN) cells (where possible) per donor and concentration.

Fifty differentially stained metaphases per donor and concentration were examined for SCE and 100 metaphases were analysed for the determination of M1, M2 and M3+ mitotic division. Proliferation indices (PI) were counted according to L a m berti et al. (1983).

For statistical evaluation of the results, the chi-square test was used for MN, and ANOVA and Student:s t test for SCE.

\section{Results and Discussion}

The ability of chloridazon to induce MN in cytokinesis blocked cells is shown in Table 1 .

Table 1

Induction of $\mathrm{MN}$ in sheep peripheral lymphocytes treated with chlorizanon from two donors

\begin{tabular}{|c|c|c|c|c|c|}
\hline \multirow{2}{*}{$\begin{array}{l}\text { Concentration } \\
\text { of chloridazon (M) }\end{array}$} & \multirow{2}{*}{$\begin{array}{l}\text { Number } \\
\text { of } B N\end{array}$} & \multirow{2}{*}{$\begin{array}{c}\text { Number } \\
\text { of } \mathrm{MN} \text { in } \mathrm{BN}\end{array}$} & \multicolumn{2}{|c|}{ Distribution of $\mathrm{MN}$} & \multirow{2}{*}{$\begin{array}{l}\% \mathrm{MN} \\
\pm \mathrm{SD}\end{array}$} \\
\hline & & & $1 \mathrm{MN}$ & $2 \mathrm{MN}$ & \\
\hline Control DMSO & 2090 & 21 & 21 & - & $1.0 \pm 0.10$ \\
\hline $7 \times 10^{-6}$ & 1982 & $22^{\mathrm{a}}$ & 16 & 3 & $1.1 \pm 0.12$ \\
\hline $7 \times 10^{-5}$ & 2096 & $30^{a}$ & 30 & - & $1.4 \pm 0.12$ \\
\hline $7 \times 10^{-4}$ & 2200 & $40^{*}$ & 40 & - & $1.8 \pm 0.13$ \\
\hline $\operatorname{MMC}(0.4 \mu \mathrm{M})$ & 2050 & $69 * * *$ & 63 & 3 & $3.4 \pm 1.19$ \\
\hline
\end{tabular}

*, ***: statistical significance $(\mathrm{P}<0.05$ and $\mathrm{P}<0.001$, respectively)

a: nonsignificant differences

$\mathrm{BN}$ : binucleated cell

SD: standard deviation

The effect of the herbicide on induction of $\mathrm{MN}$ in sheep peripheral lymphocytes showed a dose-related increase (Fig. 1) with statistical significance only at the highest concentration tested $\left(7 \times 10^{-4} \mathrm{M}, \mathrm{P}<0.05, \chi\right.$-square). No significant differences in the induction of $\mathrm{MNi}$ were found at both lower concentrations $\left(7 \times 10^{-5} \mathrm{M}\right.$ and $\left.7 \times 10^{-6} \mathrm{M}\right)$.

The cytokinesis block micronucleus (CBMN) technique is considered to be a reliable method for the detection of MN, mainly after improvement according to Fenech and Morley (1985), using cytochalasin B to arrest cytokinesis and discriminate between undivided cells and those which undergo one or more divisions. CBMN technique appears to be sensitive enough to detect both clastogenicity and aneuploidy.

Fig. 1

Dose-dependence of MN and SCE in sheep lymphocytes concentration $1: 7 \times 10^{-6} \mathrm{M}$ concentration $2: 7 \times 10^{-5} \mathrm{M}$ concentration $3: 7 \times 10^{-4} \mathrm{M}$

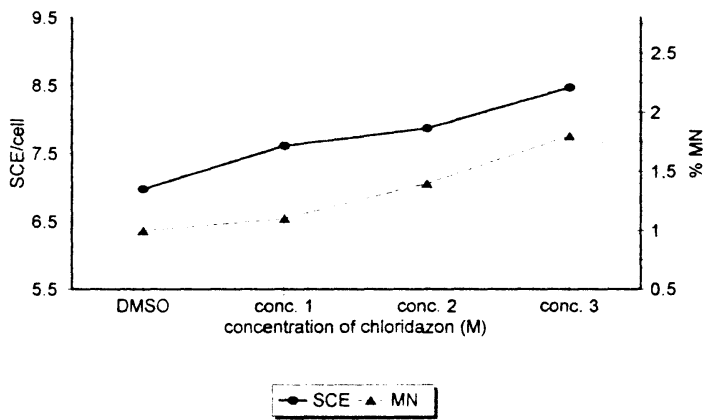

The genotoxic potential of herbicides has been investigated by several researchers using the MN assay, too. Ribas et al. (1996ab) evaluated effects of herbicides such as alachlor, maleic hydrazide and 
Table 2

Induction of SCE in sheep peripheral lymphocytes chloridazon from two donors

\begin{tabular}{|l|l|l|l|}
\hline $\begin{array}{l}\text { Chloridazon } \\
\text { Treatment }\end{array}$ & Concentration $(\mathrm{M})$ & SCE/cell $\pm \mathrm{SD}$ & PI \\
\hline $24 \mathrm{~h}(-\mathrm{S} 9)$ & Control DMSO & $6.98 \pm 1.75$ & 1.435 \\
& $7 \times 10^{-6}$ & $7.61 \pm 3.45^{\mathrm{a}}$ & 1.435 \\
& $7 \times 10^{-5}$ & $7.87 \pm 2.10^{\mathrm{a}}$ & 1.415 \\
& $7 \times 10^{-4}$ & $8.47 \pm 2.98^{\mathrm{x}}$ & 1.485 \\
& $\mathrm{NaN}_{3}, 1 \mu \mathrm{g} / \mathrm{ml}$ & $9.60 \pm 3.05^{\mathrm{xxx}}$ & 1.50 \\
\hline \multirow{2}{*}{$\mathrm{h}(+\mathrm{S} 9)$} & Control DMSO $^{-6}$ & $6.95 \pm 2.31$ & 1.50 \\
& $7 \times 10^{-6}$ & $7.59 \pm 2.02^{\mathrm{a}}$ & 1.48 \\
& $7 \times 10^{-5}$ & $9.08 \pm 2.68^{\mathrm{x}}$ & 1.49 \\
& $7 \times 10^{-4}$ & $9.42 \pm 2.64^{\times \mathrm{x}}$ & 1.49 \\
& $\mathrm{CPA}, 4 \mu \mathrm{g} / \mathrm{ml}$ & $9.85 \pm 2.86^{\mathrm{xxx}}$ & 1.60 \\
\hline
\end{tabular}

$x, x x . x \times x$ : statistical significance $(P<0.05, P<0.01, P<0.001$, respectively. ANOVA, Student's t-test) a: non-significant differences

SD: standard deviation

trifluralin for their genotoxicity in human peripheral blood lymphocyte cultures. They found the ability of alachlor to induce micronuclei in cytokinesis blocked cells in one of the two donors shows a dose-related increase of $\mathrm{MN}$ with statistical significance $(\mathrm{P}<0.001)$ at the highest concentration tested $(20 \mu \mathrm{g} / \mathrm{ml})$, similar to that seen in CA assay. Their results obtained by means of maleic hydrazide in the $\mathrm{MN}$ assay, however, did not reveal such effect on human lymphocytes. The significant increase in the number of $\mathrm{MN}$ cells was observed in four cases at the highest concentration of trifluralin $(100 \mu \mathrm{g} / \mathrm{ml}$ and $200 \mu \mathrm{g} / \mathrm{ml}$, respectively). The results obtained with and without metabolic activation ( $\mathrm{S} 9$ fraction) indicate that the substance does not affect lymphocyte cultures at the selected concentrations. Similarly, Kevekordes et al. (1997) tested the nitro musk compounds in MN tests with human lymphocytes in vitro and the human hepatoma cell line Hep G2. The nitro musk agents are used in some technical products as herbicide formulations and these agents revealed no genotoxicity in the $\mathrm{MN}$ test.

The effects of chloridazon to induce SCE in sheep peripheral lymphocytes in vitro are shown in Table 2 and Fig. 1. A clear dose-dependence of SCE was seen in experiments in the presence and in the absence of metabolic activation.

In cultures exposed to chloridazon for the last $24 \mathrm{~h}$ without $\mathrm{S} 9$, a significant increase of SCE was obtained only at the highest concentration $\left(7 \times 10^{-4} \mathrm{M}, \mathrm{P}<0.05\right.$, ANOVA and Student's t-test). No positive effect was found after treatment with both lower concentration $\left(7 \times 10^{-5} \mathrm{M}\right.$ and $\left.7 \times 10^{-6} \mathrm{M}\right)$.

Treatments with herbicide for $2 \mathrm{~h}$ with S9 caused more pronounced differences in SCE frequencies compared to controls. The enhancement of SCE/cell induced chloridazon at concentrations of $7 \times 10^{-5} \mathrm{M}$ and $7 \times 10^{-4} \mathrm{M}$ (except for the lowest dose) was significant $(\mathrm{P}<0.05$ and $\mathrm{P}<0.01$, respectively, Tab. 2$)$.

The reduction of proliferation indices and cell-cycle delays was not revealed. Differences observed in PI were reflected only by variations of lymphocyte subpopulations to PHA stimulation (Palma et al. 1993).

Our findings indicate that chloridazon exerts only a weak effect on induction of chromosomal damage. In cultures without $\mathrm{S} 9$ fraction chloridazon induced a positive effect only at the highest concentration of $7 \times 10^{-4} \mathrm{M}(\mathrm{P}<0.05)$. These results correspond with our previous findings from the $\mathrm{CA}$ assays in sheep peripheral lymphocytes treated with 
chloridazon, with and without metabolic activation (Šiviková and Dianovský 1997). As far as we are aware, there is no information on genotoxicity or mutagenicity of chloridazon available.

SCE assay is considered to be a more sensitive technique for detecting exposure to mutagenic agents than chromosome aberrations (Morimoto et al. 1985; Tucker and Preston 1996). In in vitro genotoxicity assays S9 fraction is commonly used for metabolic activation of chemical agents. For risk assessment purposes for humans, however, positive results observed in experiments with $S 9$ fraction have less relevance than those seen without $S 9$, because the preparation of the $S 9$ fraction and the cofactors used contribute to detoxification of the substance in contrast to normal conditions (Johnson et al. 1996).

Our results demostrate the sensitivity of sheep peripheral lymphocytes to chloridazon exposure in both tests. A significant positive correlation between MN and SCE and concentrations of the herbicide confirms acceptability of both tests for this purpose. Regarding the fact that the herbicide induced chromosome damage (MN and SCE) only at the highest concentration $\left(7 \times 10^{-4} \mathrm{M}\right)$, it can be stated that there is only a weak genotoxic effect of chloridazon in sheep peripheral lymphocytes in vitro.

\section{Indukcia mikrojadier a sesterských chromatidových výmen v periférnych lymfocytoch oviec po pôsobení chloridazonu}

Sledovali sme vplyv herbicídu chloridazonu na indukciu mikrojadier (MN) a sesterských chromatidových výmen (SCE) v periférnych lymfocytoch oviec in vitro. Chloridazon sa vo všetkých testovaných koncentráciách prejavil zvýšením frekvencií MN a SCE, štatisticky významné zvýšenie bolo pri koncentrácii $7 \times 10^{-4} \mathrm{M}(\mathrm{P}<0.05)$. Obe nižŠie koncentrácie $(7$ $\times 10^{-5}$ a $7 \times 10^{-6} \mathrm{M}$ ) nemali vplyv na indukciu MN a SCE.

Herbicíd sme testovali i $\mathrm{v}$ prítomnosti aktivačnej frakcie $\mathrm{S} 9$, kde sme zaznamenali zvýšenie hodnôt SCE/bunku pri koncentrácii chloridazonu $7 \times 10^{-5}$ a $7 \times 10^{-4} \mathrm{M}$, ktoré boli štatisticky významné $(P<0.05$, resp. $P<0.01)$.

Indukciu oneskoreného bunkového cyklu a redukciu proliferačných indexov sme v našich experimentoch nezaznamenali.

Z našich výsledkov vyplýva, že herbicíd chloridazon má slabý vplyv na indukciu sledovaných chromozomových zmien.

\section{Acknowledgements}

This work was supported by grant No.4342/1997 of the Ministry of Education and Science of the Slovak Republic.

\section{References}

CANTERS, K .J., DE SNOO, G. R.1993: Chemical treat to birds and mammals in the Netherlands. Rev. Environ. Contam. Toxicol. 130:1-29

CARRANO, A. V.. THOMPSON, L. H., LINDE, P. A., MINKLER, J. L.1978: Sister chromatid exchanges as indicator of mutagenity. Nature 271: 551-553

CREMLYN, R. 1978: Herbicides. In.: CREMLYN R.: Pesticides - Preparation and Mode of Action. Jonh Wiley and Sons, Ltd, Chichester 158 p.

CREMLYN, R.1985: Pesticides. Publishing House of Technical Literature, Praha, 244 p.

DELVO, H. W. 1987: Inputs outlook and situation report, economic research service, IOS-6, U. S. Department of Agriculture, Washington. D. C.

DELVO, H. W. 1987, in RIBAS, G., SURRALLÉS, J., CARBONELL, E., XAMENA, N. CREUS, R., MARCOS, R. 1996: Genotoxic evaluation of the herbicide trifluralin on human lymphocytes exposed in vitro. Mutat. Res. 371:15-21 
FENECH, M., MORLEY, A. A.1985: Measurement of micronuclei in lymphocytes. Mutat. Res. 147: 29-36

HRELIA. P., MOROTTI, M., SCOTTI, M., VIGAGNI, F., PAOLINI, M., PEROCCO, P., CANTELLI FORTI, G.1990: Genotoxic risk associated with pesticides: evidences on short-term tests. Pharmacol. Res. 22: 93-94

HRELIA. P., VIGAGNI, F., MOROTTI, M.. CANTELLI FORTI, G.1991: Genotoxic effects of pesticides and their value in the prediction of risk to humans. Pharmacol. Toxicol. 69:18

JOHNSON, T. E., UMBENHAUER, D. R., GALLOWAY, S. M. 1996: Human liver S-9 metabolic activation: Proficiency in cytogenetic assays and comparison with phenobarbital/ $\beta$-naphtoflavone or Aroclor 1254 induced rat S-9. Environ. Mol. Mutagen. 28: 51-59

KALE, P. G., PETTY, B. T. Jr., WOLKER, S., FORD, J. B., DEHKORDI, N., TARASIA, S., TASIE, B. O., KALE, R.. SOHNI. Y. R.1995: Mutagenicity testing of nine herbicides and pesticides currently used in agriculture. Environ. Mol. Mutagen. 25: 148-153

KEVEKORDES, S., ZAULIG, A., DUNKELBERG, H.1997: Genotoxicity of nitro musks in the micronucleus test with human lymphocytes in vitro and the human hepatoma cell line Hep G2. Toxicol. Lett. 91:13-17

LAMBERTI, L., PONZETTO, B. P., ARDITO. G.1983: Cell kinetics and sister chromatid exchanges frequency in human lymphocytes. Mutat. Res. 120:193-199

MARON, D. M...AMES, B. N. 1983: Revised methods for the Salmonella mutagenicity test. Mutat. Res. 113: 173-215

MLYNARCÍKOVÁ, H., GUZY, J., LEGÁTH, J.1996:Observing of chloridazone effect in animal organism in subcellular level. Toxicol. Lett. 88: 31

MORIMOTO, K.. SATO-MIZUNO, M., KOIZUMI, A.1985: Sister-chromatid exchanges and cell-cycle kinetics in human lymphocyte cultures exposed to alkylating mutagens: apparent deformity in dose-response relationships. Mutat. Res. 152:187-196

NORPPA. H., LUOMAHAARA, S., HEIKANEN, H., ROTH, S., SORSA, M., RENZI, L.,LINDHOLM, C.1993: Micronucleus assay in lymphocytes as a tool to biomonitor human exposure to aneuploidogens and clastogens. Environ. Health Perspect. Suppl. 101:139-143

PALMA, V., TUDON, H., BUENTELLO, L., NAVA. S., OSTROCKY, P., SALAMANCA, F.1993: Methods for the analysis of cellular kinetics in PHA-stimulated blood lymphocytes using BrdU incorporation. Mutat. Res. 286: $267-273$

PERRY, P., WOLFF, S.1974: New Giemsa methods for differential staining of sister chromatids. Nature 251: 156158

POKORNÁ, Z., STRNADOVÁ. V., RUBEŚ, J., ZUDOVÁ Z.1996: Mutagenicity of feeds and bovine milk in districts with different levels of environmental pollution. Vet. Med.-Czech 41: 351-358

RIBAS, G., SURRALLÉS, J., CARBONELL, E., XAMENA, N., CREUS, A., MARCOS, R.1996a: Genotoxicity of the herbicides alachlor and maleic hydrazide in cultured human lymphocytes. Mutagenesis 11: 221-227

RIBAS, G., SURRALLÉS, J., CARBONELL. E., XAMENA, N., CREUS, A., MARCOS, R.1996b: Genotoxic evaluation of the herbicide trifluralin on human lymphocytes exposed in vitro. Mutat. Res. 371: 15-21

SURRALLÉS, J., CARBONELL, E., MARCOS. R., DEGRASSI, F., ANTOCCIA, A., TANZARELLA, C.1992: A collaborative study on the improvement of the micronucleus test in cultured human lymphocytes. Mutagenesis 7: $407-410$

SURRALLÉS. J., XAMENA, N., CREUS, A.. CATALÁN, J., NORPPA, H., MARCOS, R.1995: Induction of micronuclei by five pyrethroid insecticides in whole-blood and isolated human lymphocyte cultures. Mutat. Res. 341: 169-134

SIVIKOVA. K., DIANOVSKÝ, J.1997: Cytogenetic effects of the herbicide chloridazon in cultured sheep lymphocytes. Acta Vet. Hung. 45: 11-16

TUCKER, J. D., PRESTON, R. J.1996: Chromosome aberrations, micronuclei, aneuploidy, sister chromatid exchanges, and cancer risk assessment. Mutat. Res. 365: 147-159

Address for correspondence:

MVDr. E. Piešová

Department of Veterinary Genetics

University of Veterinary Medicine

Komenského 73

04181 Košice

Slovak Republic

Phone: 421953211115

Fax: 42195767675

E-mail: vetuniv@csearn 